\title{
Nursing Role In The Implementation Of Emergency Patient With Interruption Of The Cardiovascular Systemat The Review Of Nurse Knowledge In Aisyiyah Hospital Ponorogo
}

\author{
Gunarto $^{1}$, Dwi Setiyani, Prima Iswahyudi, Hildania \\ ${ }^{\prime}$ Aisyiyah Hospital Ponorogo, East Java, Indonesia \\ Corresponding author : gunartomanuk@gmail.com
}

\begin{abstract}
Background: Knowledge or cognitive is a very important domain in shaping one's actions or overt behavior.

Purpose : The purpose of this study is to analyze the relationship of knowledge and role of nurses in the handling of emergency patients in Aisyiyah Ponorogo General Hospital

Methods : The design of correlative quantitative research with cross sectional research approach. This study uses independent variables. Knowledge of the nurse is the result of know to improve the behavior of nurse as executor in handling of emergency of cardiovascular system disorder and dependent variable of nurse role that is nurse behavior in handling of emergency of cardiovascular system disorder. The population is all nurses of IGD and ICU / ICCU in RSU Aisyiyah Ponorogo with sample of 25 respondents in Purposive Sampling. Data were collected using questionnaire and observation sheet then analyzed by Spearman Rank Correlation test.

Result : The results of research almost half (36\%) as many as 9 respondents have good knowledge. Spearmank Rank Correlation sig. (2-tailed) with 0.05>0.007).

Conclusion : The nurse's knowledge is greatly influenced by the level of education of a person, and is linked, either directly or indirectly to the role of nurses in the treatment of emergency in patients with cardiovascular system disorders.
\end{abstract}

Keywords : Nurse Knowledge, Nurse Role, Emergency Management

How to Cite: Gunarto., Setiani, D., Iswahyudi, P., \& Hildania. (2018). Nursing Role In The Implementation Of Emergency Patient Patients With Interruption Of The Cardiovascular Systemat The Review Of Nurse Knowledge In Aisyiyah Hospital Ponorogo. Journal Of Nursing Practice. 1(2). 41-46 


\section{BACKGROUND}

Cardiovascular system is a system that generally play the role of circulating blood throughout the body, as well as carrying oxygen and nutrients to all body tissues and transport all waste substances. The function of the cardiovascular system is to supply and supply oxygen and nutrients throughout the tissues and organs required in the metabolic process. The first rank as a cause of death is a cardiovascular system disorder that is a heart attack or acute myocardial infarction (Bandero, 2008).

Cardiovascular system disorder is a condition in which the blood supply in a part of the heart stops so that the heart muscle cells experience death. This is very worrying because often a sudden attack, generally in men aged 35-55 years, without any previous complaints (Farissa, 2012).

This disorder is caused by the coronary artery desease (CAD) artery. When a person suffers a heart attack, the flow of blood into one or more coronary arteries will decrease. This decrease in blood flow causes ischemia and infarction that result in necrosis of the heart muscle. This may occur due to the narrowing of one or more coronary arteries or due to vasospasm. In each of these circumstances, narrowing results in a decrease in blood flow that can lead to ischemia, but results in infarction or necrosis (Oman, 2008).

Heart attacks ranked first as the cause of death in the United States. Reported annually there are about 476,124 deaths caused by a heart attack. By 2015 an estimated 1,100,000 Americans have a heart attack of 650,000 first-time attacks and 450,000 repeat attacks. Population with lower education was higher due to incompliance in treatment and rehabilitation on a regular basis (Muhammad 2011). WHO (2011) heart attack is the first cause of death in the world (WHO, 2015).

Cardiovascular system disorders tend to increase as a cause of death in Indonesia. Data from household health survey (SKRT) in 2016 shows that the proportion of this disease increases from year to year as the cause of death. In 2010 the deaths from heart disease were only 5.9\% years. Year 2016 increased to 19\%. The national census (2011) showed that deaths from cardiovascular disease were 26.4\%. East Java Provincial Health Office in 2010 obtained cases with cardiovascular disorders 7.32 per 1000 population (Farissa, 2012).

Increased emergency cases each year include cardiovascular system outbreaks and community demands for the quality of emergency nursing service services by nurses as implementers of health care in handling emergency outbreaks is crucial for improvement where the primary goal of emergency assistance is to provide care that will benefit patients before they receive definitive treatment (Faridah, 2009).

A preliminary study conducted at RS Aisyiyah Ponorogo on February 13, 2017 obtained data of patients who experience cardiovascular system disorders that come in Emergency Installation (IGD) RSisy Aisyiyah Ponorogo, knowledge of nurses in handling disorders of the cardiovascular system is less than the maximum, found that there is a significant increase every year. In 2013 the incidence of 450 patients with death rate $5.4 \%$ and an increase in incidence rate in 2014 that is 525 patients with mortality $1.76 \%$ in 2015 incidence rate of 650 patients with $7.9 \%$ mortality rate in 2016 number incidence of 772 patients with mortality $10.5 \%$. So the number of patients with cardiovascular disorders from 2013 to 2014 has increased significantly.

There are nurses who have not attended the training $(85 \%)$ or 12 nurses have attended emergency cardiovascular care training $(15 \%)$ or 2 nurses have not attended emergency cardiovascular disorders training. Of the ten nurses who have attended the training, there are 3 nurses with certificates whose validity period has expired. Similarly, in the ICU / ICCU room 2 get nurses who have not received ICU / ICCU training and 8 of them have received 
training. This can affect the immediate and responsive nurses in providing emergency treatment with cardiovascular disorders.

One of the professional nursing practice places is an emergency unit that helps clients in providing emergency services to maintain life, prevent worsening conditions and improve recovery. Emergency emergency assistance includes many important organs of the body including the cardiovascular system in which the high mortality rate due to cardiovascular disease and two thirds died within two hours after the attack (Faridah, 2009).

\section{OBJECTIVE}

To know the knowledge and role of nurses in the implementation of emergency patient handling with cardiovascular system disorder.

\section{METHODS}

This study uses independent variables. Knowledge of the nurse is the result of know to improve the behavior of nurse as executor in handling of emergency of cardiovascular system disorder and dependent variable of nurse role that is nurse behavior in handling of emergency of cardiovascular system disorder. The population is all nurses of IGD and ICU / ICCU in RSU Aisyiyah Ponorogo with sample of 25 respondents in Purposive Sampling. Data were collected using questionnaire and observation sheet then analyzed by Spearman Rank Correlation test.

\section{RESULTS}

Table 1. Characteristics of respondents by age, sex, education level, and length of work of respondents

\begin{tabular}{clcc}
\hline No & \multicolumn{1}{c}{ Characteristic } & $\sum$ & \% \\
\hline 1 & Age & & \\
& $20-25$ & 0 & 0 \\
& $26-30$ & 7 & 28 \\
& $31-35$ & 9 & 36 \\
& $36-40$ & 6 & 24 \\
& $>40$ & 3 & 12 \\
2 & Sex & & \\
& Man & 13 & 52 \\
& Women & 12 & 48 \\
Education level & & \\
& D III & 25 & 100 \\
& S1 & 0 & 0 \\
& Ners & 0 & 0 \\
Length of work & & \\
& $<3$ years & 1 & 4 \\
& 3-5 years & 0 & 0 \\
& 6-10 years & 12 & 48 \\
& 11-15 years & 5 & 20 \\
& 16-20 years & 5 & 20 \\
& $>$ 20 years & 2 & 8 \\
$\quad$ Total & $\mathbf{2 5}$ & $\mathbf{1 0 0}$ \\
\hline
\end{tabular}


Table 2. Frequency Distribution Based on Nurse Role in Implementation of Emergency Patient Handling With Cardiovascular System Disorder in IGD and ICU / ICCU Aisyiyah Public Hospital Year 2017

\begin{tabular}{lccc}
\hline \multicolumn{2}{c}{ Role of nurse } & $\sum$ & $\%$ \\
\hline Good & 20 & 80 \\
Enough & & 5 & 20 \\
Lack & & 0 & 0 \\
& Total & 25 & 100 \\
\hline
\end{tabular}

Table 3. Statistical test results

\begin{tabular}{|c|c|c|c|c|}
\hline & & & Knowledge & Role \\
\hline \multirow[t]{6}{*}{$\begin{array}{l}\text { Spearman's } \\
\text { rho }\end{array}$} & \multirow[t]{3}{*}{ Knowledge } & $\begin{array}{l}\text { Correlation } \\
\text { Coefficient }\end{array}$ & 1.000 & .419 \\
\hline & & $\begin{array}{l}\text { Sig. } \\
\text { tailed) }\end{array}$ & & .037 \\
\hline & & $\mathrm{N}$ & 25 & 25 \\
\hline & \multirow[t]{3}{*}{ Role } & $\begin{array}{l}\text { Correlation } \\
\text { Coefficient }\end{array}$ & .419 & 1.000 \\
\hline & & $\begin{array}{l}\text { Sig. } \\
\text { tailed) }\end{array}$ & .037 & \\
\hline & & $\mathrm{N}$ & 25 & 25 \\
\hline
\end{tabular}

\section{DISCUSSION}

Nurse Knowledge In Implementing Emergency Patient Handling With Cardiovascular System Disorder.

Knowledge is the result of knowing, and this happens after people have sensed a particular object. Knowledge or cognitive is a very important domain in shaping one's actions or overt behavior (Notoatmojo, 2013). Knowledge is a very important domain for the formation of the behavior and actions of a person, because from experience and research turns out that behavior based on knowledge will be more lasting (Notoatmojo, 2013).

The results of research that has been conducted from 49 respondents about nurse knowledge found that almost half (36\%) as many as 9 respondents have good knowledge. the knowledge of either or less of a nurse is influenced by several factors, and the underlying theory. Factors that influence knowledge include education, because education is a guidance given someone against the development of others towards a certain aspiration (Suwarno, 2007 quoted in Nursalam, Pariani, 2011).

This is supported by the results of research in Table 1 shows that almost all (100\%) as many as 25 respondents have a diploma III nursing education. The higher the education will be the better the level of knowledge, otherwise less education will hamper the development of one's attitude toward new values. This is in accordance with the theory expressed Atkinson in Nursalam (2012) that the fundamental impulse in a person who is motivated is the need for achievement (need for achivement) or achieving education, apart from the theory is also supported by the theory that Kuncoroningrat (2007) cited by Nursalam (2011) that the higher the education of a person, the more easy to receive information so that more knowledge is owned.

Table shows that almost half of respondents who have good knowledge (36\%) as many as 9 respondents have ages between 31 years to 35 years, this indicates Age is the age of 
individuals who are counted from birth to birthday. Age is one of the factors that influence the knowledge of nurses because age can be a measure of physical and mental readiness of a person in the face of problems. (Notoatmojo, 2013).

The nurse's knowledge is influenced by the age factor, it indicates that the older age, maturity level and strength of the person will be more mature in thinking and working. The older the person's age the more constructive in using coping of problems encountered.

\section{Role of Nurse as Executor in Implementation of Emergency Patient Handling With Cardiovascular System Disorder.}

The role of nurses in fact during this nurse is still not so understand and run its role, especially for the laughing who works at the hospital where if seen from the portion is still a nurse who runs its role as a supporter of medical services (Vocational). One professional nursing practice is an emergency unit that helps clients provide emergency services to maintain life, prevent worsening conditions and improve recovery (Skeet, 2015). This emergency assistance includes many important organs of the body such as the cardiovascular system in which the high mortality rate due to cardiovascular disease and two thirds died within two hours after the attack (Skeet, 2015).

Table 3 mostly ( $80 \%)$ as many as 20 respondents have a good role. This is because the nurse has a good nurse knowledge, as evidenced from the results of research on 49 respondents (nurses) most (84\%) as many as 21 respondents have good knowledge.

Table 4 shows that almost half (48\%) of 12 respondents have a good role is male sex. Sex is a classification of humans into biological groups, there is a theory that states that women are older than men (Kuncoroningrat, 2006).

Table 5 shows that almost half $(48 \%)$ of 12 respondents have a good role with a working period of 6 to 10 years. This is influenced because with the length of work between 6 to 10 years, the knowledge gained by the respondents are still attached and the feeling to work hard is still high, when compared to the respondents with longer work longer, they tend to be bored with the work. Work is not a source of fun but is more a tedious, repetitive and challenging way of making a living (Swanburg, 2007).

Nurses in emergency treatment besides being provided with training are of the male gender preferred, because men have more power in taking emergency action than women.

\section{Relationship Knowledge And Role Of Nurse In Implementation Of Emergency Patient Handling With Cardiovascular System Disorder.}

A study of 25 respondents indicated that nurses' knowledge was related to the role of nurses in the treatment of emergency in patients with cardiovascular system disorders. Statistical test using "Spearman rank correlation" with 5\% significance level obtained Sig price. (2-tailed) is 0.037. because the coefficient alpha $>$ Sig. (2-tailed) then the hypothesis is accepted $(0.05>$ 0.037). the conclusion is that there is a relationship between the knowledge and role of nurses in the treatment of emergency in patients with cardiovascular system disorders.

The relationship of nurse knowledge with nurse role is very closely related to the theory expressed by Soeroso (2013) that the factors that influence the knowledge of a nurse will influence the role of nurse in him, with the knowledge of the nurse can give a result that is the improvement of work performance. Improved work performance is the role of nurses in emergency treatment in patients with cardiovascular system disorders 


\section{CONCLUSION}

The nurse's knowledge is greatly influenced by the level of education of a person, and is linked, either directly or indirectly to the role of nurses in the treatment of emergency in patients with cardiovascular system disorders

The relationship of nurse knowledge with nurse role is very closely related to the theory expressed by Soeroso (2013) that the factors that influence the knowledge of a nurse will influence the role of nurse in him, with the knowledge of the nurse can give a result that is the improvement of work performance. Improved work performance is the role of nurses in emergency treatment in patients with cardiovascular system disorders.

\section{REFERENCES}

Baradero, M., Dayrit Mary Wilfrid., Siswadi, Yakobus. (2008). Klien Gangguan Kardiovaskuler : Seri Asuhan Keperawatan. Jakarta : EGC.

Faridah, VN. Hubungan Pengetahuan Perawat Dan Peran Perawat Sebagai Pelaksana Dalam Penanganan Pasien Gawat Darurat Dengan Gangguan Sistem Kardiovaskuler. Vol. 2 No. IV Desember 2009 (Diunduh 9 Februari 2016)

Farissa IP. Komplikasi Pada Pasien Infark Miokard Akut ST-elevasi (STEMI) yang mendapatkan maupun tidak mendapatkan terapi reserfusi. 2012 (diunduh 4 Desember 2016). Tersedia dari : URL : HYPERLINK.

Gaffar, La Ode Jumadi. (2009). Pengantar Keperawatan Professional. Jakarta, EGC

Ismani, Mila. (2011). Etika Keperawatan. Widya Medika : Jakarta. Cv. Info Medika

Joe. (2009). Peran dan Fungsi Perawat. Jakarta Salemba Medika

Kozier, Barbara. (2010). Fundamental Of Nursing. Red Wood. Adison Wesley. Jakarta : EGC

PPNI. (2009). Keperawatan dan Praktek Keperawatan. Jakarta, Dewan Pimpinan Pusat PPNI

PPNI. (2015). Standar Praktek Keperawatan. Jakarta, Pengurus Pusat PPNI

Priharjo, Robert. (2008). Konsep dan Perspektif Praktik Keperawatan Profesional. Edisi 2. Buku Kedokteran EGC : Jakarta

Skeet, Muriel (2015). Tindakan Paramedis Terhadap Kegawatan Dan Pertolongan Pertama Edisi 5. Alih bahasa Silvana Evi Linda Dan Indah Nurmala Dewi. EGC, Jakarta. (Hal 74-79)

Widiasih, Ni Luh. (2013). Peran Perawat Anastesi Dalam Kegawatdaruratan. Surabaya (Makalah disampaikan pada Seminar Kursus Penyegaran Keperawatan Anestesi). Hal 27-34. Penulis adalah staf pengajar STIKES Muhammadiyah Lamongan 